\title{
Enhancement of some key physiological, morphological and biochemical traits of watermelon induced by Trichoderma harzianum fungi
}

\section{Aprimoramento de algumas características fisiológicas, morfológicas e bioquímicas essenciais de melancia induzidas pelo fungo Trichoderma harzianum}

\author{
Hasnain Waheed ${ }^{1 *}$; Muhammad Awais Khan²; Hafiz Muhammad Tayyab khan²; \\ Muhammad Mansoor Javaid ${ }^{1}$; Faiz Ur Rahman ${ }^{3}$; Muhammad Muzammal Aslam³
}

\section{Highlights:}

In this study we check the possibility that using Trichoderma harzianum could improve the productivity and quality of watermelon.

Plant growth medium inoculated with T. harzianum at $1 \times 10^{4} \mathrm{cfu}, 1.25 \times 10^{4} \mathrm{cfu}$ and $1.50 \times 10^{4} \mathrm{cfu}$.

It was observed that plant grown in growth medium inoculated with $T$. harzianum has direct relation with growth and quality of watermelon.

Results revealed that increase in the level of $T$. harzianum from 0 to $1.5 \times 10^{4} \mathrm{cfu}$ in watermelon roots had enhanced their growth.

It is found that higher level of T. harzianum $1.5 \times 10^{4} \mathrm{cfu}$ is the most effective in improving yield and quality of watermelon.

\begin{abstract}
A pot study was performed under greenhouse condition to check the possibility that using Trichoderma harzianum could improve the growth, production and quality of watermelon genotype. Plant growth medium inoculated with T. harzianum at $1 \times 10^{4} \mathrm{cfu}, 1.25 \times 10^{4} \mathrm{cfu}$ and $1.50 \times 10^{4} \mathrm{cfu}$ respectively, while un-inoculated with fungi used as control treatment. Plant growth medium inoculated with higher concentration $\left(1.50 \times 10^{4} \mathrm{cfu}\right)$ of $T$. harzianum significantly increased plant root and shoot length and brings early flowering. The higher values of plant fresh and dry weight, leaf area, stomatal conductance, transpiration rate, net photosynthesis rate and number of fruit per plant of watermelon was obtained with $1.50 \times 10^{4} \mathrm{cfu}$. However, T. harzianum levels of $1.50 \times 10^{4} \mathrm{cfu}$ and $1.25 \times 10^{4} \mathrm{cfu}$ produced statistically similar results for carbohydrate content, total soluble solids, vitamin A content and $\beta$-carotene of watermelon. It was observed that plant grown in growth medium inoculated with $T$. harzianum has direct relation with growth and quality of watermelon. Compared to all tested levels, the higher level of T. harzianum $1.5 \times 10^{4} \mathrm{cfu}$ is the most effective in improving growth, yield and quality of watermelon genotype (cv. Sugar baby).
\end{abstract}

Key words: Citrullus lanatus. Chlorophyll content. Growth and quality. Photosynthetic activity.

\footnotetext{
${ }^{1}$ Department of Agronomy, College of Agriculture, University of Sargodha, Sargodha, Pakistan. E-mail: hasnainwaheed90@, yahoo.com; mmansoorjavaid@gmail.com

2 Department of Horticulture, College of Agriculture, University of Sargodha, Sargodha, Pakistan. E-mail: awaiskhan230@gmail. com; hafiztayyabkhan100@yahoo.com

3 Zhengzhou Fruit Research Institute, Chinese Academy of Agricultural Sciences, Zhengzhou, China. E-mail: faizi3636@gmail. com; muzamal.aslam@yahoo.com

* Author for correspondence
} 


\section{Resumo}

Um estudo em vasos foi realizado em casa de vegetação para verificar a possibilidade do uso de Trichoderma harzianum para melhorar o crescimento, a produção e a qualidade da melancia 'Sugar baby' (Citrullus lanatus). Para tanto, foram utilizados meios de crescimento vegetal inoculado com $T$. harzianum a $1 \times 10^{4}$ ufc, $1,25 \times 10^{4}$ ufc e $1,50 \times 10^{4}$ ufc, respectivamente, enquanto o meio não inoculado com fungos foi utilizado como tratamento controle. O meio de crescimento das plantas inoculado com maior concentração $\left(1,50 \times 10^{4} \mathrm{ufc}\right)$ de $T$. harzianum aumentou significativamente o comprimento da raiz e da parte aérea das plantas e promoveu o florescimento precoce. Os maiores valores de peso fresco e seco da planta, área foliar, condutância estomática, taxa de transpiração, taxa líquida de fotossíntese e número de frutos por planta de melancia foram obtidos com 1,50 $\times 10^{4} \mathrm{ufc}$. No entanto, os níveis de $T$. harzianum de $1,50 \times 10^{4}$ ufc e $1,25 \times 10^{4} \mathrm{cfu}$ produziram resultados estatisticamente semelhantes para $\mathrm{o}$ teor de carboidratos, sólidos solúveis totais, teor de vitamina A e $\beta$-caroteno de melancia. Observou-se que as plantas cultivadas em meio de crescimento inoculado com $T$. harzianum têm relação direta com o crescimento e a qualidade da melancia. Comparado a todos os níveis testados, o nível mais alto de $T$. harzianum $1,5 \times 10^{4}$ ufc é o mais eficaz para melhorar o crescimento, o rendimento e a qualidade do genótipo da melancia 'Sugar baby'.

Palavras-chave: Citrullus lanatus. Teor de clorofila. Crescimento e qualidade. Atividade fotossintética.

\section{Introduction}

Watermelon (Citrullus lanatus) is an annual crop and cultivated on an area of 3.24 million hectare (Food and Agriculture Organization [FAO], 2018). It has been cultivated on commercial level in more than 96 countries of the world (Guner, Wehner, \& Pitrat, 2008) including Pakistan. The world's watermelon production exceeds 103 million tons (FAO, 2018). Due to its high commercial values it is essential to identify the new approaches to improve its quality and production.

Now a day's consumers are more apprehensive about the consumption of fruit treated with fungicides, because their active compounds caused various health problems and environmental pollution (Nicolopoulou-Stamati, Maipas, Kotampasi, Stamatis, \& Hens, 2016). By the usage of extensive chemical fungicides at pre and postharvest levels caused the development of resistant fungi strains (Hao, Li, Hu, Yang, \& Rizwan-ul-Haq, 2011; Sánchez-Torres \& Tuset, 2011). However, it is the need to establish alternative methods to improve fruit yield with fungicide application that cause low toxicity and environmental hazards (Palou, Smilanick, \& Droby, 2008).
The endophytes impart beneficial effects on plant growth and important for agricultural ecosystems because they decrease the soil and water pollution as well as reduced the need for fertilizers (Khan, Hussain, Al-Harrasi, Al-Rawahi, $\&$ Le, 2013). Endophytic fungi are vital and novel resource of naturally bioactive compounds having potential applications in agriculture. Plant beneficial organisms, especially endophytic fungi, are mainly under study in the innovation of natural commodities (Kusari \& Spiteller, 2011). Because it is the beneficial component of plants that resist against harsh environments (Redman, Seehan, Stout, Rodriquez, \& Henson, 2002), plant protection (Omacini, Chaneton, Ghersa, \& Mueller, 2001; Bailey et al., 2006), development of plant (Ernst, Mendgen, \& Wirsel, 2003) and produce herbicidal activities when in association with their hosts. Endophytic fungi live within a plant's tissue without causing any disease symptoms or apparent injury to the host (Kogel, Franken, \& Hückelhoven, 2006). Shiomi, Silvia, Melo, Nunes and Bettiol (2006) reported that endophytic fungi are some of the most unexplored and diverse group of organisms that engaged in symbiotic associations with higher life forms and may produce beneficial substances 
for the host crop. Although variety, environmental division and plant host acceptability of endophytic fungi are not more detailed identified till now (Arnold, Maynard, \& Gilbert, 2001; Higgins, Arnold, Miadlikowska, Sarvate, \& Lutzoni, 2007). Therefore it will be of great necessity if more economically valuable endophytic fungi are identified.

The Trichoderma specie has capability to act as bio-control agents against plant pathogens and to be used in agriculture ecosystem, both for yield enhancement and disease control (Harman, 2006). It has the ability to improve the plant growth and productivity (Haggag, 2010; Lindsey \& Baker, 1967) either in the presence or absence of other microorganisms and that they can induce disease suppression in soils (Sharma, Sharma, \& Prabha, 2012). The Trichoderma harzianum have also been known to improve the growth and productivity of various crops. Some strains of $T$. harzianum establish robust and long lasting colonization of root surfaces penetrating into the epidermis (Harman, 2000). This colonization by T. harzianum often augmented the root growth and crop productivity as well as provides resistance to various abiotic stresses through improvement in mineral absorption (Mwangi, Monda, Okoth, \& Jefwa, 2011).

With best of our knowledge no work has been done to evaluate the impact of endophytic fungi ( $T$. harzianum) on growth and quality of watermelon. Therefore, present study was planned with the objectives of (i) To check the effect of T. harzianum on growth, production and quality of watermelon genotype (ii) To determine the endophytic fungi (T. harzianum) associated with watermelon are pathogenic/beneficial and do/do not affect the growth of watermelon genotype (iii) To evaluate the efficacy of $T$. harzianum under greenhouse conditions.

\section{Material and Methods}

Site description

A pot experiment was conducted in greenhouse to investigate the influence of Trichoderma harzianum on growth, production and quality of watermelon 'Sugar baby' (Citrullus lanatus) at Department of Horticulture (Latitude $31.41{ }^{\circ} \mathrm{N}$, Longitude 74.17 ${ }^{\circ} \mathrm{E}$ and Altitude $194.4 \mathrm{~m}$ ), College of Agriculture, University of Sargodha, Pakistan, during 20152016.

\section{Plant and fungal materials}

The seeds of watermelon were obtained from Ayyub Agricultural Research Institute, Faisalabad, Punjab, Pakistan. The T. harzianum isolate T-203 was obtained from a laboratory culture collection from department of plant pathology, Punjab University, Lahore, Pakistan and multiplied on potato dextrose agar (PDA) medium in laboratory conditions. The fresh potatoes $(250 \mathrm{~g})$ were peeled, washed, cut into small pieces and boiled in distilled water $(1 \mathrm{~L})$ in a microwave oven for three to four minutes. Then $20 \mathrm{~g}$ potato starch and enough water was added to make volume of $1 \mathrm{~L}$ and then glucose and agar were mixed and stirred vigorously and autoclaved at $121^{\circ} \mathrm{C}$ for 20 minutes. For bacterial growth inhibition streptomycin $5 \mathrm{mg} / \mathrm{L}$ was mixed in the media. Pouring of the media was done into autoclaved $(9 \mathrm{~cm})$ petri plates. All the work was done in the controlled condition of laminar flow. Sterile glassware along with obligatory instruments employ throughout the testing. Fungus ( $T$. harzianum) culture was inoculated on petri plates $(9 \mathrm{~cm})$ under laminar flow chamber. In each petri plate 5 bits were inoculated. Afterward the plates were enveloped with parafilm and incubated for 4-5 weeks at $25^{\circ} \mathrm{C}$ under alternating cycle of light and darkness. Usually the initial fungal growth started after 4-5 days of inoculation. The growth of fungi was recorded on weekly basis. The T. harzianum from the pure culture were preserved on PDA slants at $8^{\circ} \mathrm{C}$. 


\section{Experimental detail and treatments}

The experiment was conducted in a completely randomized design (CRD) with four replications. The five seeds per pot of watermelon genotype (cv. Sugar baby) were sown in earthen pots $\left(12^{\prime \prime} \times 9^{\prime \prime}\right)$ filled with sterilized soil $(\mathrm{pH}$ of 7.8, organic matter $0.79 \%, 0.51 \% \mathrm{~N}, 11 \mathrm{mg} / \mathrm{kg}$ available $\mathrm{P}$, and $115 \mathrm{mg} /$ $\mathrm{kg}$ available $\mathrm{K}$ ) and sand mixture (1: $1 \mathrm{v} / \mathrm{v})$ with $8.5 \mathrm{~kg}$ soil and kept under greenhouse conditions (at $28 \pm 2^{\circ} \mathrm{C}$ under alternate cycles of $12 / 12 \mathrm{~h}$ light and darkness). The inoculum was mixed with sandy loam soil to a final inoculum density of $T$. harzianum at the levels of $1 \times 10^{4} \mathrm{cfu}, 1.25 \times 10^{4}$ cfu and $1.50 \times 10^{4}$ cfu respectively, while in control plants growth medium was not inoculated with fungi. Recommended doses of NPK fertilizers at 160,70 and $50 \mathrm{~kg} \mathrm{ha}^{-1}$, respectively were added to each pot and the required fertilizers were calculated based on fertilizers required for acre furrow slice weight. Before, sowing, seeds were disinfected with $5 \%$ sodium hypochlorite solution for 15 minutes, followed by repeated washing with double distilled water. Thinning was done to maintain one plant per pot at one week after germination. The pots were irrigated in such that water is not to be a limiting factor.

\section{Calculation of colonizing frequency}

Colonization frequency (CF) was calculated as described by Suryanarayanan, Venkatesan and Murali (2003). Briefly, proper time of incubation was given for colonizing frequency counting. Colonization frequency (\%) of Trichoderma specie was equal to the number of segments colonized by single specie divided by the total number of segments observed by 100 .

\section{Colonization Frequency $(\%)=$}

Number of segment colonized by fungi $\times 100$

Total number of segment observed

\section{Determination of colonial forming unit (cfu)}

The actual concentrations of the fungal suspensions were determined using a spiral plater (Eddy-Jet, IUL Instruments, Germany). The solution after adjusted with $1 / 4$ ringer solution was diluted 10, 100 and 1000 times. Then, the original and diluted solutions were placed in the spiral plater and a sub-sample of $37.3 \mu \mathrm{L}$ was automatically plated on potato dextrose agar (PDA). The number of colonies was counted every day for a period of 14 days. CFU was then determined using a counter mat supplied by the manufacturer.

\section{Collection of data}

Number of days taken to flower initiation were counted from day after seed germination to flower bud opening. The number of fruit per plant was counted manually by physical observation. To calculate the leaf area $\left(\mathrm{cm}^{2}\right)$, leaf was collected from plants and measured with the help of leaf area meter. Data regarding the number of leaves per plant, shoot and root length, fresh and dry weight were recorded according to standard procedure.

Carbohydrate contents of watermelon were determined by following the standard methods as described by Southgate (1991). A refractometer ATAGO, RS-5000 (Atago, Japan), was used to measure total soluble solids (TSS) of juice. The instrument was calibrated with distilled water before and during use. Firstly begin the calibration of refractometer lifted up the daylight plate and place 2-3 drops of distilled water on top of the prism assembly. Then closed the daylight plate so the water spreads across the entire surface of the prism without any air bubbles or dry spots. Allow the extracted juice sample to sit on the clean prism for approximately 15 seconds. This allows the sample to adjust to the ambient temperature of the refractometer. Hold the refractometer in the direction of a natural light source and look into the eyepiece. The reading of TSS (\%) was recorded 
with the refractometer that was pointed directly at a light source (Saleem, Malik, \& Farooq, 2007; Youssef \& Hussien, 2020).

Net photosynthesis rate $\left(\mu \mathrm{mol} \quad \mathrm{m}^{-2} \mathrm{~s}^{-1}\right)$, transpiration rate $\left(\mathrm{mmol} \mathrm{\textrm {m } ^ { - 2 }} \mathrm{s}^{-1}\right)$ and stomatal conductance $\left(\mathrm{mmol} \mathrm{m} \mathrm{m}^{-2} \mathrm{~s}^{-1}\right)$ was estimated by using a portable infrared gas analyzer (CI-340 Portable Photosynthesis System, CID Biosciences, USA). The measurements were noted between 10:00 am to 11:00 pm and fully expanded leaves were selected for readings.

Chlorophyll content was measured with portable leaf chlorophyll meter (SPAD 502, Minolta Co., Osaka, Japan). Vitamin A and $\beta$-carotene contents were estimated according to the method of Stancher and Zonta (1982).

\section{Statistical analysis}

Statistical analysis of the data was carried out in CRD layout, by using software statistix 8.1 analysis of variance (ANOVA) technique and treatments means were compared by using Tukey's honest significant difference (HSD) test at 5\% probability level (Steel, Torrie, \& Dickey, 1997). The graphical representation of the data was done by using software Sigma Plot 11.0.

\section{Results}

The days taken to flower initiation was significantly affected by different levels of Trichoderma harzianum (Table 1). When the means were calculated over the four T. harzianum levels $\left(0,1 \times 10^{4}, 1.25 \times 10^{4}\right.$ and $\left.1.5 \times 10^{4} \mathrm{cfu}\right)$, the days taken to flower initiation were significantly lower than plants which were grown in media that was not inoculated with $T$. harzianum. With increasing level of $T$. harzianum the plants take less time to initiate flowering (Table 1). The number of fruits per plant enhanced significantly with application of $T$. harzianum. The highest number of fruit per plant (7.5) was recorded in plants that were grown in growth media inoculated with $1.5 \times 10^{4} \mathrm{cfu} T$. harzianum. Increasing the levels of $T$. harzianum from 0 to $1.5 \times 10^{4} \mathrm{cfu}$ in the plant culture media gradually enhanced the leaf area of watermelon (Table 1). However, the plants culture media inoculated with $1.5 \times 10^{4} \mathrm{cfu}$ level of T. harzianum demonstrated a higher leaf area $\left(95.8 \mathrm{~cm}^{2}\right)$ than lower levels and in control treatment. The increases in number of leaves per plant that were imposed by T. harzianum were higher in the plants grown in growth media treated with $1.5 \times 10^{4} \mathrm{cfu}$ as compared to others treatments. However, the minimum number of leaves per plant (17.0) was observed in plants which were not treated with T. harzianum. Results indicated that shoot and root length of watermelon respond significantly to different levels of T. harzianum (Table 1 and 2). The accumulation of T. harzianum in plants growing media raised the shoot and root length with the maximum values obtained under $T$. harzianum inoculation level of $1.5 \times 10^{4} \mathrm{cfu}$. This indicated that addition of $T$. harzianum in plant culture media increased the shoot and root length of watermelon than control. However, the lowest values of shoot $(118.2 \mathrm{~cm})$ and root $(32.2 \mathrm{~cm})$ length of watermelon was recorded where inoculation of no addition of T. harzianum in plant culture media was performed (Table 1 and 2). 


\section{Table 1}

Days taken to flower initiation, number of fruit per plant, leaf area, number of leaves per plant and shoot length of watermelon (cv. Sugar baby) as influenced by different levels of endophytic fungi (Trichoderma harzianum)

\begin{tabular}{cccccc}
\hline $\begin{array}{c}\text { Endophytic fungi } \\
\text { levels (cfu EF) }\end{array}$ & $\begin{array}{c}\text { Days taken to } \\
\text { flower initiation }\end{array}$ & $\begin{array}{c}\text { Number of } \\
\text { fruits per plant }\end{array}$ & $\begin{array}{c}\text { leaf area } \\
\left(\mathbf{c m}^{\mathbf{2}}\right)\end{array}$ & $\begin{array}{c}\text { Number of } \\
\text { leaves per plant }\end{array}$ & $\begin{array}{c}\text { Shoot length } \\
(\mathbf{c m})\end{array}$ \\
\hline $0($ Control) & $78.4^{\mathrm{a}} \pm 1.21$ & $4.0^{\mathrm{c}} \pm 0.59$ & $74.3^{\mathrm{d}} \pm 1.12$ & $17.0^{\mathrm{d}} \pm 0.56$ & $118.2^{\mathrm{c}} \pm 1.34$ \\
$1 \times 10^{4}$ & $68.5^{\mathrm{b}} \pm 0.73$ & $5.4^{\mathrm{b}} \pm 0.67$ & $81.6^{\mathrm{c}} \pm 1.43$ & $20.6^{\mathrm{c}} \pm 0.73$ & $130.5^{\mathrm{b}} \pm 1.12$ \\
$1.25 \times 10^{4}$ & $63.6^{\mathrm{c}} \pm 1.31$ & $7.0^{\mathrm{a}} \pm 0.45$ & $88.7^{\mathrm{b}} \pm 0.98$ & $26.7^{\mathrm{b}} \pm 0.66$ & $139.3^{\mathrm{a}} \pm 1.33$ \\
$1.5 \times 10^{4}$ & $61.0^{\mathrm{c}} \pm 1.02$ & $7.5^{\mathrm{a}} \pm 0.63$ & $95.8^{\mathrm{a}} \pm 1.07$ & $30.3^{\mathrm{a}} \pm 0.78$ & $143.6^{\mathrm{a}} \pm 1.23$ \\
\hline HSD $(\mathbf{0 . 0 5})$ & 2.72 & 1.06 & 3.61 & 2.50 & 5.82 \\
\hline
\end{tabular}

Means in the column sharing the same letter did not differ with each other according to Tukey's honest significant difference test at $5 \%$ probability level and \pm indicate standard error $(n=4)$.

Table 2

Root length, fresh weight, dry weight, carbohydrates contents and total soluble solids of watermelon (cv. Sugar baby) as influenced by different levels of endophytic fungi (Trichoderma harzianum)

\begin{tabular}{|c|c|c|c|c|c|}
\hline $\begin{array}{l}\text { Endophytic fungi } \\
\text { levels (cfu EF) }\end{array}$ & $\begin{array}{l}\text { Root length } \\
\text { (cm) }\end{array}$ & $\begin{array}{c}\text { Fresh weight } \\
\text { (g) }\end{array}$ & $\begin{array}{l}\text { Dry weight } \\
\text { (g) }\end{array}$ & $\begin{array}{c}\text { Carbohydrates } \\
\text { contents (g) }\end{array}$ & $\begin{array}{l}\text { Total soluble } \\
\text { solids ( }{ }^{\circ} \text { brix) }\end{array}$ \\
\hline 0 (Control) & $32.6^{\mathrm{d}} \pm 0.78$ & $759.1^{\mathrm{d}} \pm 1.14$ & $71.3^{\mathrm{d}} \pm 0.55$ & $7.7^{b} \pm 0.23$ & $8.8^{c} \pm 0.34$ \\
\hline $1 \times 10^{4}$ & $38.2^{\mathrm{c}} \pm 0.81$ & $793.6^{c} \pm 1.02$ & $77.5^{c} \pm 0.34$ & $8.0^{\mathrm{b}} \pm 0.32$ & $9.6^{\mathrm{b}} \pm 0.39$ \\
\hline $1.25 \times 10^{4}$ & $44.0^{\mathrm{b}} \pm 0.68$ & $874.3^{b} \pm 1.12$ & $86.0^{\mathrm{b}} \pm 0.48$ & $8.46^{\mathrm{a}} \pm 0.36$ & $9.9^{\mathrm{a}} \pm 0.44$ \\
\hline $1.5 \times 10^{4}$ & $48.7^{\mathrm{a}} \pm 0.66$ & $903.8^{\mathrm{a}} \pm 1.06$ & $93.3^{\mathrm{a}} \pm 0.42$ & $8.6^{\mathrm{a}} \pm 0.33$ & $10.1^{\mathrm{a}} \pm 0.28$ \\
\hline HSD (0.05) & 1.84 & 14.21 & 2.13 & 0.32 & 0.21 \\
\hline
\end{tabular}

Means in the column sharing the same letter did not differ with each other according to Tukey's honest significant difference test at $5 \%$ probability level and \pm indicate standard error $(n=4)$.

In case of fresh and dry weight, all tested levels of $T$. harzianum significantly increased the fresh and dry weight of watermelon. The T. harzianum levels were ranked as follows: $1.5 \times 10^{4} \mathrm{cfu}>1.25$ $\times 10^{4} \mathrm{cfu}>1 \times 10^{4} \mathrm{cfu}>0$. Compared with control, the fresh and dry weight with $1.5 \times 10^{4} \mathrm{cfu}$ was boosted significantly by $903.8 \mathrm{~g}(16 \%)$ and $93.3 \mathrm{~g}$ $(23 \%)$ respectively (Table 2$)$. The lowest value of fresh and dry weight was observed under control treatment.

A substantial response of watermelon carbohydrates contents was observed to various levels of T. harzianum. By increasing T. harzianum levels induced an obvious increase in the carbohydrates contents (Table 2). Except for the level of $1 \times 10^{4} \mathrm{cfu}$ in which watermelon exhibited less carbohydrates contents compared with other levels of $T$. harzianum. The higher levels $\left(1.5 \times 10^{4}\right.$ and $1.25 \times 10^{4} \mathrm{cfu}$ ) of $T$. harzianum produced statistically similar results for carbohydrates contents. The total soluble solids (TSS) of watermelons are presented in table 2 when the plants were grown in culture media that was mixed with different levels of $T$. harzianum. In the juice, the presence of T. harzianum markedly increased the TSS in comparison with control as the highest level of T. harzianum $(1.5 \times$ $\left.10^{4} \mathrm{cfu}\right)$ induced the maximum value of TSS (10.1 obrix) among all tested levels. However, there was no significant difference between $1.5 \times 10^{4}$ and 1.25 $\times 10^{4} \mathrm{cfu}$ levels of T. harzianum for TSS (Table 2). 
Net photosynthesis rate of watermelon increased linearly with increase in $T$. harzianum levels $(0,1$ $\times 10^{4}, 1.25 \times 10^{4}$ and $\left.1.5 \times 10^{4} \mathrm{cfu}\right)$. Among all the levels of $T$. harzianum, maximum net photosynthesis rate $\left(8.91 \mu \mathrm{mol} \mathrm{m}^{-2} \mathrm{~s}^{-1}\right)$ of watermelon was obtained with $T$. harzianum mixed in culture media at $1.5 \times$ $10^{4} \mathrm{cfu}$ which was followed by $1 \times 10^{4}$ and $1.25 \times 10^{4}$ cfu. The least net photosynthesis rate $\left(8.02 \mu \mathrm{mol} \mathrm{m}^{-2}\right.$ $\left.\mathrm{s}^{-1}\right)$ was recorded where plant culture media was not treated with T. harzianum (Figure 1-a). Transpiration rate of watermelon plant treated with various levels of T. harzianum showed similar pattern to that of net photosynthesis rate (Figure 1-b). Compared to control, addition T. harzianum at $1.5 \times 10^{4} \mathrm{cfu}$ measured highest transpiration rate $(5.36 \mathrm{mmol}$ $\mathrm{m}^{-2} \mathrm{~s}^{-1}$ ) which as followed by $1.25 \times 10^{4} \mathrm{cfu}$ level of T. harzianum (Figure 1-b). In case of stomatal conductance, plant grown on culture media mixed with $1.5 \times 10^{4} \mathrm{cfu}$ level of $T$. harzianum observed highest stomatal conductance $\left(802.0 \mathrm{mmol} \mathrm{m}^{-2} \mathrm{~s}^{-1}\right)$ of watermelon and lowest $\left(564.0 \mathrm{mmol} \mathrm{m}^{-2} \mathrm{~s}^{-1}\right)$ was detected where plant growth media was not treated with T. harzianum (Figure 2-a).

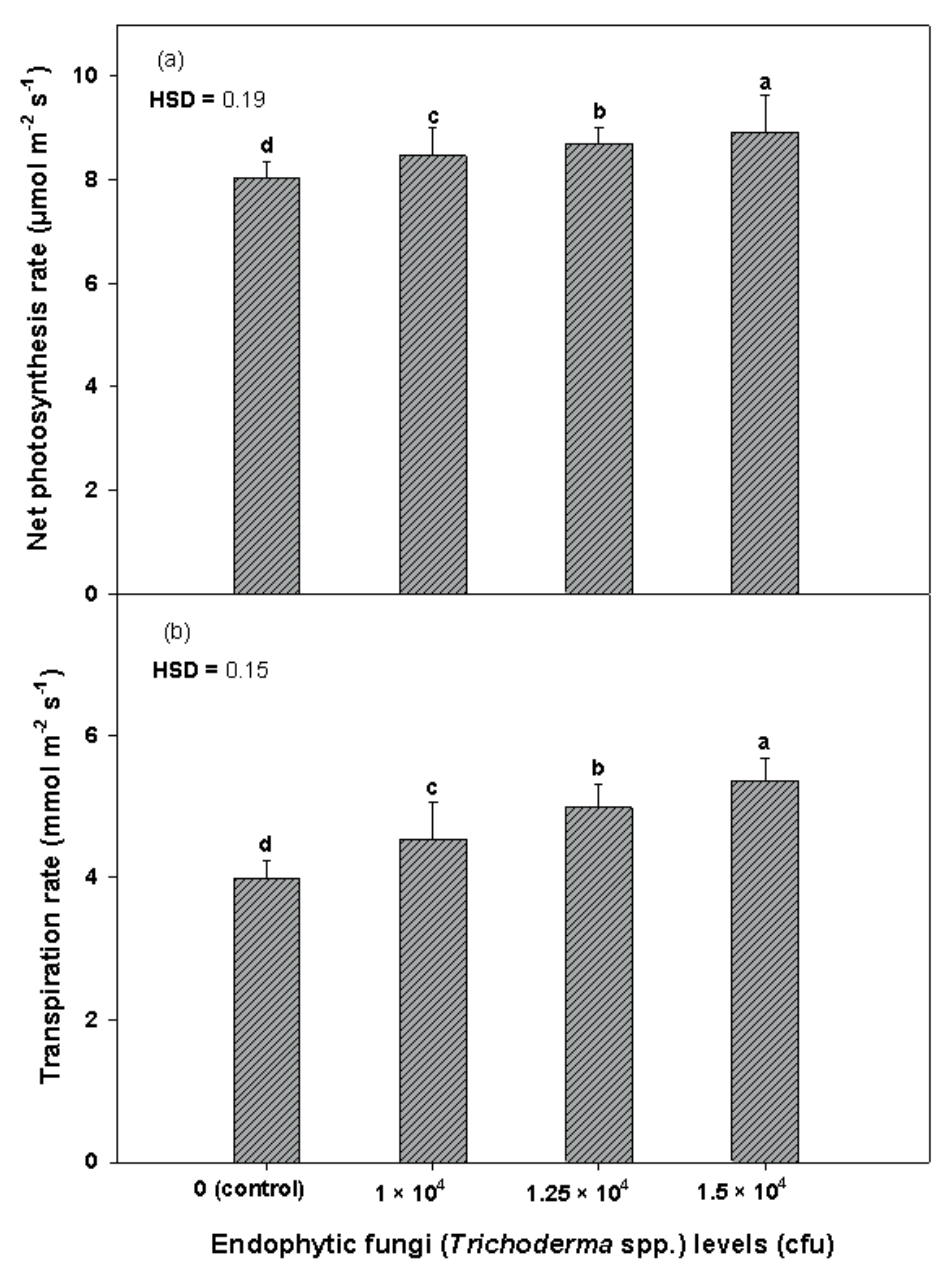

Figure 1. Influence of different levels of endophytic fungi (Trichoderma harzianum) on (a) net photosynthesis rate ( $\mu \mathrm{mol}$ $\left.\mathrm{m}^{-2} \mathrm{~s}^{-1}\right)$ and (b) transpiration rate $\left(\mathrm{mmol} \mathrm{m} \mathrm{m}^{-2} \mathrm{~s}^{-1}\right)$ of watermelon genotype. The column sharing the same letter did not differ with each other according to Tukey's honest significant difference test at $5 \%$ probability level. Vertical lines on the bars represent standard errors of the means. 


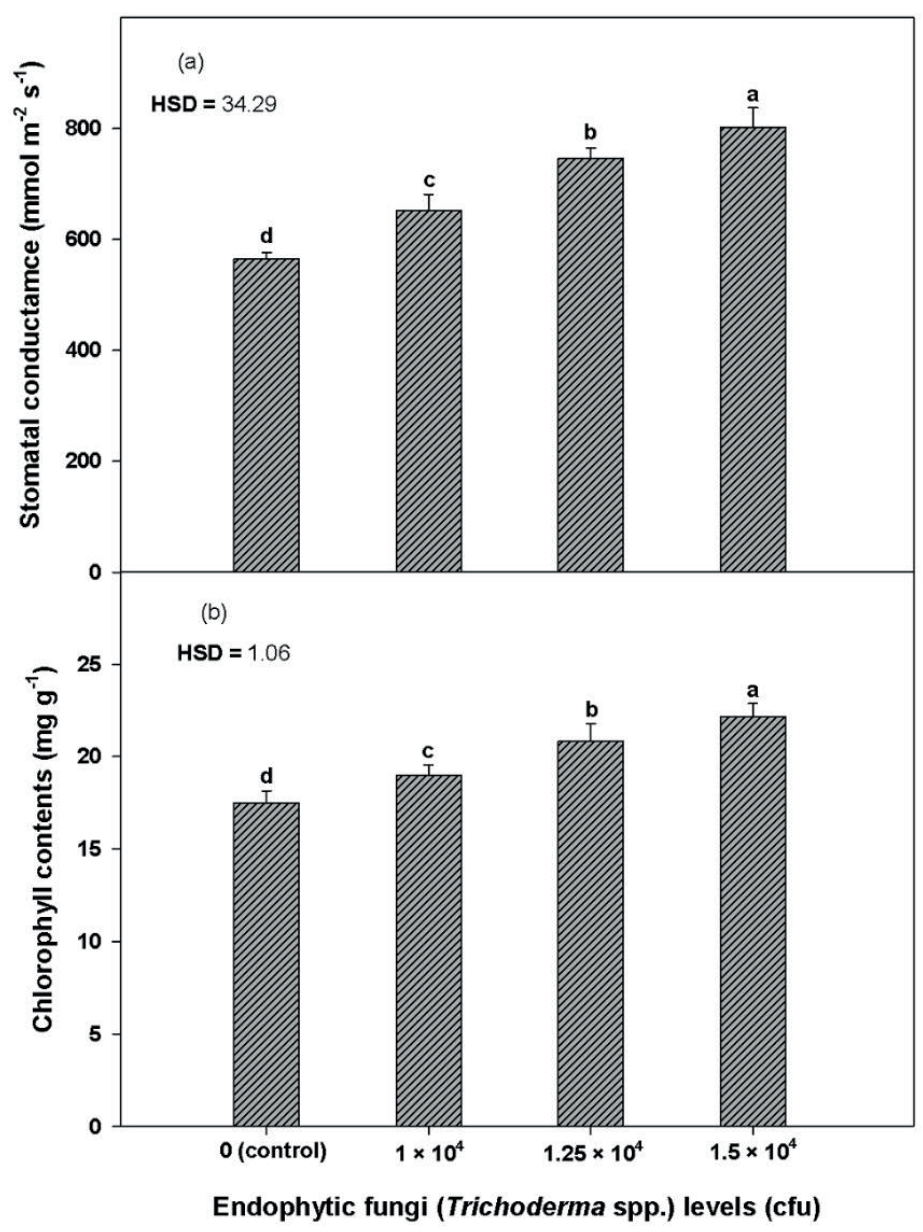

Figure 2. Influence of different levels of endophytic fungi (Trichoderma harzianum) on (a) stomatal conductance (mmol $\left.\mathrm{m}^{-2} \mathrm{~s}^{-1}\right)$ and (b) chlorophyll contents $\left(\mathrm{mg} \mathrm{g}^{-1}\right)$ of watermelon genotype. The column sharing the same letter did not differ with each other according to Tukey's honest significant difference test at $5 \%$ probability level. Vertical lines on the bars represent standard errors of the means.

As shown in figure 2-b, different levels of $T$. harzianum increased in chlorophyll content. In this study, chlorophyll content of watermelon plant showed significantly higher values at all levels of T. harzianum than control. The highest chlorophyll contents $\left(22.16 \mathrm{mg} \mathrm{g}^{-1}\right)$ were obtained where plant culture media mixed with $T$. harzianum at the rate of $1.5 \times 10^{4} \mathrm{cfu}$ (Figure 2-b). The application of T. harzianum significantly improved the amount of vitamin A contents in watermelon, however, watermelon plants grown on culture media mixed with $1 \times 10^{4} \mathrm{cfu}$ were less affected than higher levels $\left(1.25 \times 10^{4}\right.$ and $\left.1.5 \times 10^{4} \mathrm{cfu}\right)$ of $T$. harzianum. But, these higher levels were showed statistically similar effect on vitamin A contents of watermelon (Figure $3-a)$. Data in figure 3-b, showed that $\beta$-carotene contents of watermelon also increased with increasing levels of T. harzianum. No significant difference in $\beta$-Carotene was observed between lower level $\left(1 \times 10^{4} \mathrm{cfu}\right)$ of $T$. harzianum and control. However, $\beta$-Carotene of watermelon was much higher $(0.60 \mu \mathrm{g})$ with $T$. harzianum levels of $1.5 \times 10^{4} \mathrm{cfu}$ than control $(0.47 \mu \mathrm{g})$. 


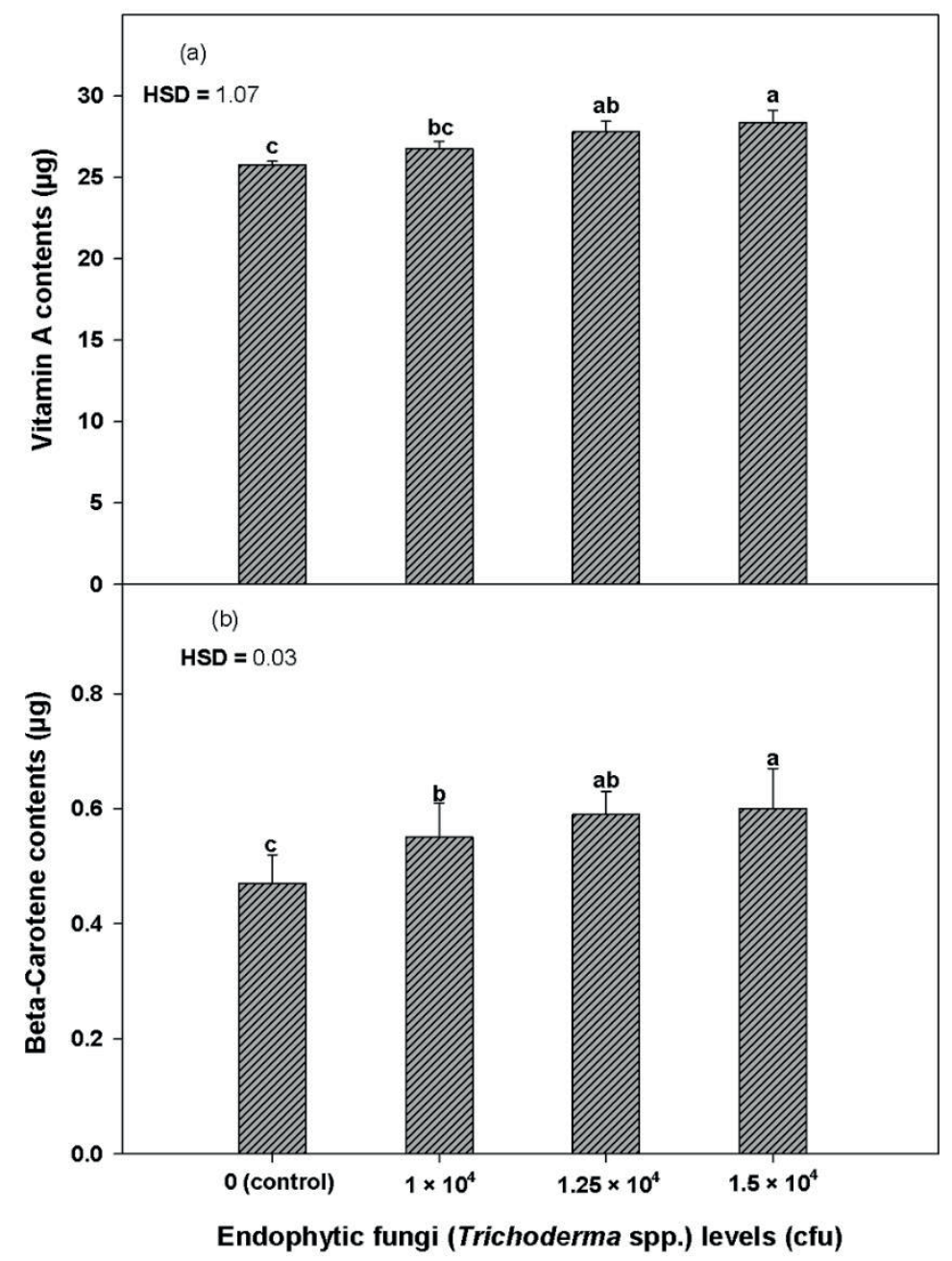

Figure 3. Influence of different levels of endophytic fungi (Trichoderma harzianum) on (a) vitamin A contents ( $\mu \mathrm{g})$ and (b) carotene contents $(\mu \mathrm{g})$ of watermelon genotype. The column sharing the same letter did not differ with each other according to Tukey's honest significant difference test at $5 \%$ probability level. Vertical lines on the bars represent standard errors of the means.

\section{Discussion}

The results demonstrated that endophytic fungi (T. harzianum) inoculated in the watermelon plants growth medium enhanced their growth as shown by the results, days to initiate flowering decreased while number of fruit per plant, leaf area and number of leaf per plant were increased with T. harzianum when applied at the level of 1.5 $\times 10^{4} \mathrm{cfu}$. The significant differences observed for different growth parameters due to application of T. harzianum could have occurred because of one or more proven functions of T. harzianum. Due to appropriate level $\left(1.5 \times 10^{4} \mathrm{cfu}\right)$ of $T$. harzianum can increase growth either due to increased nutrient intake, improved root growth, control of pathogens or eliminating growth inhibitors from the soil. Possibly, increased growth could have been as a result of production of hormones by the fungi which stimulate growth as suggested by ContrerasCornejo, Macías-Rodríguez, Cortés-Penagos and López-Bucio (2009) and Altomare, Norvell, Bjorkman and Harman (1999), or from inducing 
plant hormone production (Schulz \& Boyle, 2005). These hormones include auxin, cytokinin and gibberellins (Abdel-Monaim, Abdel-Gaid, Zayan, \& Nassef, 2014), which are important for stimulating plant growth and development (Akter, Ali, Islam, Karim, \& Razzaque, 2007).

Our results showed that inoculation of $T$. harzianum at the level of $1.5 \times 10^{4} \mathrm{cfu}$ in growing medium increased the plant shoot length, root length, fresh and dry weights as compared to the control might have been due to the production of stimulatory compounds and/or the improvement of mineral nutrient availability and uptake. These results supported by the reports of Howell (2003) and Liu, Glenn and Buckley (2008), who demonstrated the ability of $T$. harzianum to increase root area and cumulative root length, as well as significant increases in dry weight and shoot length of tomato over of the untreated control. The T. harzianum also promoted growth of cucumber and tomato (Yedidia, Srivastva, Kapulnik, \& Chet, 2001; Ozbay \& Newman, 2004). Nzanza, Marais and Soundy (2011) also reported that there was improved shoot length, root length, dry shoot and root mass when tomato plants were inoculated with T. harzianum. Harman (2000) and Shoresh and Harman (2008) also reported that Trichoderma spp. increased plant growth, shoot and root biomass and crop yield in maize. Mwangi et al. (2011) mentioned that $T$. harzianum enhanced height and root dry weights of tomato plants.

In this study, there was a positive relationship between vegetative growth, yield and qualitative parameters like carbohydrate, total soluble solids, vitamin $A$ and $\beta$-carotene content of watermelon plant. This was evident with cv. Sugar baby that presented the largest biomass and the yield. This is in agreement with Singh and Khurma (2007) who reported that a resistant crop cultivar has a comparatively better crop yield than the infected susceptible crop cultivar. Reports on increased watermelon yield with Trichoderma spp. are rare, although in this experiment of watermelon.
Similarly Nzanza, Marais and Soundy (2012) also observed an increase in tomato yield and quality with inoculation of T. harzianum.

The increase in plant physiological activities like, stomatal conductance, transpiration and net photosynthesis rate was also observed. Similarly leaf chlorophyll content was also increased in plants treated with higher concentration $\left(1.5 \times 10^{4}\right.$ cfu) of T. harzianum compared with control may be due to optimum availability of $T$. harzianum that resulted in the improvements in plant resistance to disease, plant growth and productivity (Harman, Howell, Viterbo, Chet \& Lorito, 2004) by enhancing the chlorophyll contents in leaf. Which have been proved positive response of watermelon plants toward endophytic fungi. The increased in growth could also have been due to the increased solubility of phosphate and other plant nutrients with low solubility by T. harzianum (Yedidia et al., 2001; Azarmi, Hajieghrari, \& Giglou, 2011), thus enhancing growth of the roots and shoots due to increase in the level of nutrients. It could have been due to increased uptake of nitrogen (Harman, 2000; Nzanza et al., 2011) or other nutrients at early stages of growth. It could as well be due to increased root length allowing the plants to absorb more nutrients (Yedidia et al., 2001; Mazhabi et al., 2011). The increased nutrient uptake might have led to higher photosynthetic rates required for producing enough energy used to derive the enhanced growth response (Azarmi et al., 2011).

\section{Conclusion}

The endophytic fungi (Trichoderma harzianum) improved the morphological, physiological and biochemical traits of watermelon genotype. Based on the results of this study it may be revealed that increase in the level of T. harzianum from 0 to 1.5 $\times 10^{4} \mathrm{cfu}$ in watermelon roots had enhanced their growth. Overall it can be concluded that among all the tested levels of T. harzianum the higher level $1.5 \times 10^{4} \mathrm{cfu}$ is the most effective in improving 
growth, yield and quality of watermelon genotype (cv. Sugar baby).

However, further studies should be done to determine whether there are $T$. harzianum associated with other vegetables in different agroecological zones. It is recommended that further studies should be done to come up with a method through which farmers can use T. harzianum in their fields, nurseries etc. for better yield and effective management of different biotic and abiotic stresses.

\section{Conflict of Interest}

All authors declare that they have no conflict of interest for this research article.

\section{References}

Abdel-Monaim, M. F., Abdel-Gaid, M. A., Zayan, S. A., \& Nassef, D. M. T. (2014). Enhancement of growth parameters and yield components in eggplant using antagonism of Trichoderma spp. against Fusarium wilt disease. International Journal of Phytopathology, 3(1), 33-40. doi: 10.33687/phytopath.003.01. 0510

Akter, A., Ali, E., Islam M., Karim, R., \& Razzaque, A. (2007). Effect of GA3 on growth and yield of mustard. International Journal of Sustainable Crop Production, 2(2), 16-20. Retrieved from https:// www. semanticscholar. org/paper/Effect-of-GA3on-growth-and-yield-of-mustard.-Akt

Altomare, C., Norvell, W. A., Bjorkman, T., \& Harman, G. E. (1999). Solubilization of phosphates and micronutrients by plant growth promoting and biocontrol fungus Trichoderma harzianum strain 1295-22. Applied and Environmental Microbiology, 65(7), 2926-2933. doi: 10.1128/AEM.65.7.29262933. 1999

Arnold, A. E., Maynard, Z., \& Gilbert, G. S. (2001). Fungal endophytes in dicotyledonous neotropical trees: patterns of abundance and diversity. Mycological Research, 105(12), 1502-1507. doi: 10.1017/S0 953756201004956

Azarmi, R., Hajieghrari, B., \& Giglou, A. (2011). Effect of Trichoderma isolates on tomato seedling growth response and nutrient uptake. African Journal of Biotechnology, 10(31), 5850-5855. doi: 10.5897/ AJB10.1600
Bailey, B. A., Bae, H., Strem, M. D., Roberts, D. P., Thomas, S. E., Crozier, J.,... Holmes, K. A. (2006). Fungal and plant gene expression during the colonization of cacao seedlings by endophytic isolates of four Trichoderma species. Planta, 224(6), 1449-1464. doi: 10.1007/s00425-006-0314-0

Contreras-Cornejo, H. A., Macías-Rodríguez, L., CortésPenagos, C., \& López-Bucio, J. (2009). Trichoderma virens, a plant beneficial fungus, enhances biomass production and promotes lateral root growth through an auxin-dependent mechanism in Arabidopsis. Plant Physiology, 149(3), 1579-1592. doi: 10.1104/ pp.108.130369

Ernst, M., Mendgen, K. W., \& Wirsel, S. G. R. (2003). Endophytic fungal mutualists: seedborne Stagonospora spp. enhance reed biomass production in axenic microcosms. Molecular PlantMicrobe Interactions, 16(7), 580-587. doi: 10.1094/ MPMI.2003.16.7.580

Food and Agriculture Organization (2018). FAOSTAT statistics database. Retrieved from http://www.fao. org

Guner, N., Wehner, T. C., \& Pitrat, M. (2008). Overview of potyvirus resistance in watermelon. In: M. Pitrat (Ed.), Cucurbitaceae 2008, Proceedings of the IXth EUCARPIA meeting on genetics and breeding of Cucurbitaceae. Avignon, France, pp. 445.

Haggag, W. M. (2010). Role of entophytic microorganisms in biocontrol of plant diseases. Life Science Journal, 7(2), 57-62. doi: 10.7537/marslsj070210.11

Hao, W., Li, H., Hu, M., Yang, L., \& Rizwan-ul-Haq, M. (2011). Integrated control of citrus green and blue mold and sour rot by Bacillus amyloliquefaciens in combination with tea saponin. Postharvest Biology and Technology, 59(3), 316-323. doi: 10.1016/j. postharvbio.2010.10.002

Harman, G. E. (2000). Myths and dogmas of biocontrol: changes in perceptions derived from research on Trichoderma harzianum T-22. Plant Disease, 84(4), 377-393. doi: 10.1094/PDIS.2000.84.4.377

Harman, G. E. (2006). Overview of mechanisms and uses of Trichoderma spp. Phytopathology, 96(2), 190-194. doi: 10.1094/phyto-96-0190

Harman, G. E., Howell, C. R., Viterbo, A., Chet, I., \& Lorito, M. (2004). Trichoderma spp. opportunistic, avirulent plant symbionts. Nature Reviews microbiology, 2(1), 43-56. doi: 10.1038/nrmicro797

Higgins, K. L., Arnold, A. E., Miadlikowska, J., Sarvate, S. D., \& Lutzoni, F. (2007). Phylogenetic relationships, host affinity, and geographic structure of boreal and 
arctic endophytes from three major plant lineages. Molecular Phylogenetic and Evolution, 42(2), 543555. doi: 10.1016/j.ympev.2006.07. 012

Howell, C. R. (2003). Mechanisms employed by Trichoderma species in the biological control of plant diseases: the history and evolution of current concepts. Plant Disease, 87(1), 4-10. doi: 10.1094/ PDIS. 2003.87.1.4

Khan, A. L., Hussain, J., Al-Harrasi, A., Al-Rawahi, A., \& Le, I. (2013). Endophytic fungi: resource for gibberellins and crop abiotic stress resistance. Critical Reviews in Biotechnology. 35(1), 62-74. doi: 10. $3109 / 07388551.2013 .800018$

Kogel, K. H., Franken, P., \& Hückelhoven, R. (2006). Endophyte or parasite-what decides? Current Opinion in Plant Biology, 9(4), 58-363. doi: 10.1016/j.pbi.2006.05.001

Kusari, S., \& Spiteller, M. (2011). Are we ready for industrial production of bioactive plant secondary metabolites utilizing endophytes? Natural Product Reports, 28(7), 1203-1207. doi: 10.1039/c1np00030f

Lindsey, D. L., \& Baker, R. (1967). Effect of certain fungi on dwarf tomatoes grown under gnotobiotic conditions. Phytopathology, 57(11), 1262-1263. Retrieved from https://scholar.google.com/ scholar?hl= en\&as_sdt $=0 \% 2 \mathrm{C} 5 \& \mathrm{q}=$ Effect + of + certa in + fungi + on + dwarf + tomatoes + grown + under+gnoto biotic + conditions $\&$ btnG $=$

Liu, B., Glenn, D., \& Buckley, K. (2008). Trichoderma communities in soils from organic, sustainable, and conventional farms, and their relation with southern blight of tomato. Soil Biology and Biochemistry, 40(5), 1124-1136. doi: 10.1016/j.soilbio.2007.12.005

Mazhabi, M., Nemati, H., Rouhani, H., Tehranifar, A., Moghadam, E. M., Kaveh, H., \& Rezaee, A. (2011). The effect of Trichoderma on polianthes qualitative and quantitative properties. The Journal of Animal and Plant Sciences, 21(3), 617-621. Retrieved from http://www.thejaps.org.pk/docs/21-3/28.pdf

Mwangi, M. W., Monda, E. O., Okoth, S. A., \& Jefwa, J. M. (2011). Inoculation of tomato seedlings with Trichoderma harzianum and Arbuscular Mycorrhizal Fungi and their effect on growth and control of wilt in tomato seedlings. Brazilian Journal of Microbiology, 42(2), 508-513. doi: 10.1590/S151783822011000200015

Nicolopoulou-Stamati, P., Maipas, S., Kotampasi, C., Stamatis, P., \& Hens, L. (2016). Chemical pesticides and human health: The urgent need for a new concept in agriculture. Frontiers in Public Health, 4(1), 148. doi: 10.3389/fpubh.2016.00148
Nzanza, B., Marais, D., \& Soundy, P. (2011). Tomato (Solanum lycopersicum L.) seedlings growth and development as influenced by Trichoderma harzianum and arbuscular mycorrhizal fungi. African Journal of Microbiology, 5(4), 425-431. doi: 10.5897/AJMR10.870

Nzanza, B., Marais, D., \& Soundy, P. (2012). Response of tomato (Solanum lycopersicum L.) to nursery inoculation with Trichoderma harzianum and arbuscular mycorrhizal fungi under field conditions. Acta Agriculturae Scandinavica, Section B-Soil \& Plant Science, 62(3), 209-215. doi: 10.1080/09064710. 2011.598544

Omacini, M., Chaneton, E. J., Ghersa, C. M., \& Mueller, C. B. (2001). Symbiotic fungal endophytes control insect host-parasite interaction webs. Nature, 409(6816), 78-81. doi: 10.1038/35051070

Ozbay, N., \& Newman, E. S. (2004). Effect of $T$. harzianum strains to colonize tomato roots and improve transplant growth. Pakistan Journal of Biological Sciences, 7(2), 253-257. doi: 10.3923/ pjbs.2004. 253. 257

Palou, L., Smilanick, J., \& Droby, S. (2008). Alternatives to conventional fungicides for the control of citrus postharvest green and blue molds. Stewart Postharvest Review, 4(2), 1-16. doi: 10.2212/ spr.2008.2.2

Redman, R. S., Seehan, K. B., Stout, R. G., Rodriquez, R. J., \& Henson, J. M. (2002). Thermotolerance generated by plant/fungal symbiosis. Science, 298(5598), 1581-1587. doi: 10.1126/science. 1072191

Saleem, B. A., Malik, A. U., \& Farooq, M. (2007). Effect of exogenous growth regulators application on June fruit drop and fruit quality in Citrus sinensis cv. Blood red. Pakistan Journal of Agricultural Science, 44(2), 1-6. Retrieved from https://pakjas.com.pk/ papers/328.pdf

Sánchez-Torres, P., \& Tuset, J. J. (2011). Molecular insights into fungicide resistance in sensitive and resistant Penicillium digitatum strains infecting citrus. Postharvest Biology and Technology, 59(2), 159-165. doi: 10.1016/j.postharvbio.2010.08.017

Schulz, B., \& Boyle, C. (2005). The endophytic continuum. Mycological Research, 109(6), 661-686. doi: $10.1017 / \mathrm{S} 095375620500273 \mathrm{X}$

Sharma, N., Sharma, S., \& Prabha, B. (2012). Postharvest biocontrol-new concepts and application. Crop stress and its management: perspectives and strategies (pp. 497-515). Dordrecht: Springer. 
Shiomi, H. F., Silvia, H. S. A., Melo, I. S. de, Nunes, F. V., \& Bettiol, W. (2006). Bioprospecting endophytic Bacteria for biological control of coffee leaf rust. Scientia Agricola, 63(1), 32-39. doi: 10.1590/S010390162006000100006

Shoresh, M., \& Harman, G. (2008). The relationship between increased growth and resistance induced in plants by root colonizing microbes. Plant Signaling and Behavior, 3(9), 737-739. doi: 10.4161/psb.3.9. 6605

Singh, K. S., \& Khurma, U. R. (2007). Susceptibility of six tomato cultivars to the root-knot nematode, Meloidogyne incognita. The South Pacific Journal of Natural Science, 25(1), 73-77. doi: 10.1071/ SP07013

Southgate, D. A. (1991). Determination of food carbohydrates (2a. ed). Elsevier.

Stancher, B., \& Zonta, F. (1982). High-performance liquid chromatographic determination of carotene and vitamin A and its geometric isomers in foods: applications of cheese analysis. Journal of Chromatography, 238(1), 217-225. doi: 10.1016/ S0021-9673(00)82728-4
Steel, R. G. D., Torrie, J. H., \& Dickey, D. (1997). Principles and procedures of statistics: a biometrical approach (3nd ed.). New York: McGraw Hill Book Co. Inc.

Suryanarayanan, T. S., Venkatesan, G., \& Murali, T. S. (2003). Endophytic fungal communities in leaves of tropical forest trees: diversity and distribution patterns. Current Science, 85(1), 489-493. doi: $10.1590 / \mathrm{S} 0102-33062011000400008$

Yedidia, I., Srivastva, A. K., Kapulnik, Y., \& Chet, I. (2001). Effects of Trichoderma harzianum on microelement concentrations and increased growth of cucumber plants. Plant and Soil, 235(2), 235-242. doi: 10.1023/A:1011990013955

Youssef, K., \& Hussien, A. (2020). Electrolysed water and salt solutions can reduce green and blue molds while maintain the quality properties of 'Valencia'late oranges. Postharvest Biology and Technology, 159(1), 111025. doi: 10.1016/j. postharvbio.2019.111025 
